\title{
Boron removal from metallurgical grade silicon and Si-Sn alloy through slag refining with gas blowing
}

\author{
Rowaid Al-khazraji ${ }^{1,2}$, Yaqiong Li $^{1,2}$, Lifeng Zhang ${ }^{1,2}$ \\ ${ }^{1}$ School of Metallurgical and Ecological Engineering, University \\ of Science and Technology Beijing (USTB), Beijing, 100083, China \\ ${ }^{2}$ Beijing Key Laboratory of Green Recycling and Extraction of Metal, \\ University of Science \&Technology Beijing, Beijing 100083, China
}

A combined method of slag refining and gas blowing technique were used for boron removal from metallurgical grade silicon and $75 \%$ wt $\mathrm{Si}-\mathrm{Sn}$ alloy using the $45 \% \mathrm{CaO}$ $45 \% \mathrm{SiO}_{2}-10 \% \mathrm{CaCl}_{2}$ slag with the use of $\mathrm{Ar}$ gas and $\mathrm{Ar}-20 \% \mathrm{O}_{2}$ mixed gas. Increasing gas flow rate from 50 to $250 \mathrm{ml} / \mathrm{min}$ shows enhancement in B removal. At fixed conditions the Ar- $20 \% \mathrm{O}_{2}$ mixed gas blowing shows a good removal efficiency of boron about $85 \%$ and $96 \%$ to MG and Si-Sn alloy respectively, compared with the single Ar gas blowing with $78.6 \%$ and $88 \%$ to $\mathrm{MG}$ and $\mathrm{Si}-\mathrm{Sn}$ alloy respectively. Changes in slag composition representing by decreasing in all compounds especially $\mathrm{CaCl}_{2}$ attached with increase in $\mathrm{Al}_{2} \mathrm{O}_{3}$. The B impurities after the treatment found with low intensity in Si matrix but with high intensity in slag phase and Sn phase. Boron removal controlled by mass transfer in slag phase with mass transfer coefficients of $3.38 \cdot 10^{-4} \mathrm{~cm} . \mathrm{s}^{-1}$ and $7.2 \cdot 10^{-5} \mathrm{~cm} . \mathrm{s}^{-1}$ in Si and Si-Sn alloy respectively.

Keywords: B removal; metallurgical grade silicon; Si-Sn alloy; slag refining; gas blowing

Комбинированный метод переработки шлаков методом газовой продувки был использован для удаления бора из кремния металлургического сорта и $75 \%$ сплава Si-Sn с применением $45 \% \mathrm{CaO}-45 \% \mathrm{SiO}_{2}-10 \% \mathrm{CaCl}_{2}$ шлака с использованием чистого газа $\mathrm{Ar}$ и $\mathrm{Ar}-20 \% \mathrm{O}_{2}$ смешанного газа. Увеличение расхода газа от 50 до 250 мл / мин улучшает процесс удаления В. При фиксированных условиях использование смешанного газа $\mathrm{Ar}-20 \% \mathrm{O}_{2}$ показывает хорошую әффективность удаления бора, около $85 \%$ и $96 \%$ для сплавов MG и Si-Sn, соответственно, по сравнению с одиночным газом $\operatorname{Ar}$ с $78,6 \%$ и $88 \%$ до МГ и Si-Sn, соответственно. Удаление бора контролируется массопереносом в шлаковой фазе с коэффициентами массопереноса $3,38 \cdot 10^{-4} \mathrm{~cm}^{-1}$ и $7,2 \cdot 10^{-5} \mathrm{~cm}^{-1}$ в сплаве Si и Si-Sn соответственно.

Видалення бору з металургійного кремнію $\mathrm{i}$ сплаву Si-Sn шляхом переробки шлаку з газовим продувом. Rowaid Al-khazraji, Yaqiong Li, Lifeng Zhang

Комбінований метод переробки шлаків методом газової продувки був використаний для видалення бору з кремнію з металургійного сорту і $75 \%$ сплаву Si-Sn з використанням $45 \% \mathrm{CaO}-\mathbf{4 5} \% \mathrm{SiO}_{2}-10 \% \mathrm{CaCl} 2$ шлаку з використанням газу $\mathrm{Ar}$ i $\mathrm{Ar}-20 \% \mathrm{O}_{2}$ змішаного газу. Збільшення витрати газу від 50 до 250 мл / хв показує поліпшення в видаленні В. При фіксованих умовах видування змішаним газом $\mathrm{Ar}-20 \%$ O2 показує хорошу ефективність видалення бору близько 85\% і 96\% для сплавів MG i Si-Sn відповідно, в порівнянні з одиночним газом $\mathrm{Ar} 378,6 \%$ i $88 \%$ до МГ i Si-Sn, відповідно. Видалення бору контролюється массопереносом в шлакової фазі 3 коефіцієнтами масопереносу $3,38 \cdot 10^{-4} \mathrm{~cm}^{-1}$ і $7,2 \cdot 10^{-5} \mathrm{~cm}^{-1}$ в сплаві Si i Si-Sn відповідно. 


\section{Introductions}

Recently, a lot of efforts to develop a low cost method to produce solar grade silicon (SOG-Si) of $99.9999 \%$ purity to improve the renewal energy resources due to the limitation of fossil energy [1, 2]. Solar grade silicon (SOG-Si) produce from purification of metallurgical grade silicon (MG-Si) consider the basic material in solar cell for photovoltaic (PV) applications [3]. The SOG$\mathrm{Si}$ is produced by the chemical methods such as Siemens process, fluid bed process, and silane process. However, the metallurgical methods with low energy consumption and low cost getting more attention. The metallurgical methods composed of acid leaching [4], directional solidification [5], solvent refining [6], slag refining [7], plasma treatment [8], electron beam [9], and gas blowing [10]. Each method responsible to remove a group of impurities. Most of the metallic impurities such as $\mathrm{Fe}, \mathrm{Al}, \mathrm{Ti}$, etc., can be remove by directional solidification and other methods, but B which is a typical non-metallic impurity hard to be removed from Si by this methods due it possess high segregation coefficient in $\mathrm{Si}$ and low vapor pressure. Slag refining considers an effective way to remove $\mathrm{B}$. The $\mathrm{B}$ in $\mathrm{Si}$ will combine into $\mathrm{Fe}-\mathrm{B}$ pairs and B-O metastable complexes defects with interstitial oxygen and iron [11]. It will accelerate the auger recombination and reduce the mobility ratio of minority carriers in solar cells [12]. Boron can be separated and removed from molten MG-Si in the form of borates $\left(\mathrm{BO}_{3}^{3-}\right)$ by adding $\mathrm{CaO}-\mathrm{SiO}_{2}$ containing slag. Researchers [13-17] investigated $B$ removal with the aim of decreasing $B$ content and increasing partition ratio of $B$ (LB) between slag and molten Si by optimizing the slag and the slag system of $\mathrm{CaO}-\mathrm{SiO}_{2}$ and $\mathrm{SiO}_{2}-\mathrm{CaO}-$ $\mathrm{CaF}_{2}\left(\mathrm{CaCl}_{2}-\mathrm{Na}_{2} \mathrm{O},-\mathrm{MgO},-\mathrm{BaO},-\mathrm{Al}_{2} \mathrm{O}_{3}-\mathrm{MgO}\right)$ [1317]. However, the LB values are mostly around 2, and the highest reported value is 5.5 and the B content sometimes is difficult to decrease to SOG-Si level.

In order to improve Si refining to meet the SOG-Si requirements, slag refining of MG-Si was combined with gas blowing technique. The uses of gas blowing will create B containing volatile products which can be eliminating through gas flow. The MG-Si can be purify and improve by blowing the gas or mix of gases diluted with Ar gas or other inert gas. Elements such $\mathrm{B}, \mathrm{Ca}, \mathrm{Al}, \mathrm{Ti}$ and $\mathrm{Mg}$ are easily oxidized from the Si-melt due to their lard free energy values. The gas blowing technique cannot remove impurities only, but develop stirring and slagging of the $\mathrm{Si} / \mathrm{Slag}$ melt to increase the reactions rate [18]. A combined method of slag refining with gas blowing technique were performed to enhance B removal from MG-Si and Si-Sn alloy. The effect of gas flow rate, gas type, elements distributions, changes in slag compositions, and mass transfer coefficient were investigated.

\section{Experimental}

The slag refining combined with gas blowing was performed to MG-Si and 75\% Si-Sn pre-melted alloy with the use of premelted $45 \%$ CaO $-45 \% \quad \mathrm{SiO}_{2}-10 \% \mathrm{CaCl}_{2}$ slag system in graphite crucible with $2.5 \mathrm{~cm}$ inner diameter inside resistance furnace. The initial B impurity concentration before the reaction is shown in Table 1 .

Reaction temperature was $15000 \mathrm{C}$ and for different holding time. The gases of $\mathrm{Ar}$ and $\mathrm{Ar}-20 \% \mathrm{O} 2$ were blow in the experiment with the help of $\mathrm{Al}_{2} \mathrm{O}_{3}$ lance with $5 \mathrm{~mm}$ diameter. Figure 1 shows the experiment structure. After the experiment, the graphite crucible was taken out from the furnace to cool down. Later, the slag was separated mechanically from the MG-Si or the $75 \%$ wt Si-Sn alloy. The MG-Si and the $75 \%$ wt SiSn alloy were treated with acid leaching and the B content was examine through inductively coupled plasma atomic emission spectroscopy inductively coupled plasma (ICPAES). The X-ray fluorescence (XRF) was use to find the changes in slag mass ratio before and after slag refining. Electron probe microanalyzer (EPMA) used to observe the element distribution.

\section{Results and discussions}

\subsection{Flow rate effect}

The gas flow rate effect in slag refining was studied with the use of Ar gas for MG$\mathrm{Si}$ and $75 \%$ wt Si-Sn alloy with $30 \mathrm{~min}$ holding time. The experiments preformed

Table 1. Impurity concentrations (ppmw) in Interaction materials

\begin{tabular}{|c|c|c|c|c|c||}
\hline \hline Impurity & MG-Si & $\mathrm{Sn}$ & $\mathrm{CaO}$ & $\mathrm{SiO}_{2}$ & $\mathrm{CaCl}_{2}$ \\
\hline $\mathrm{B}$ & 18.3 & 1 & 1.2 & 0.2 & 0.5 \\
\hline
\end{tabular}




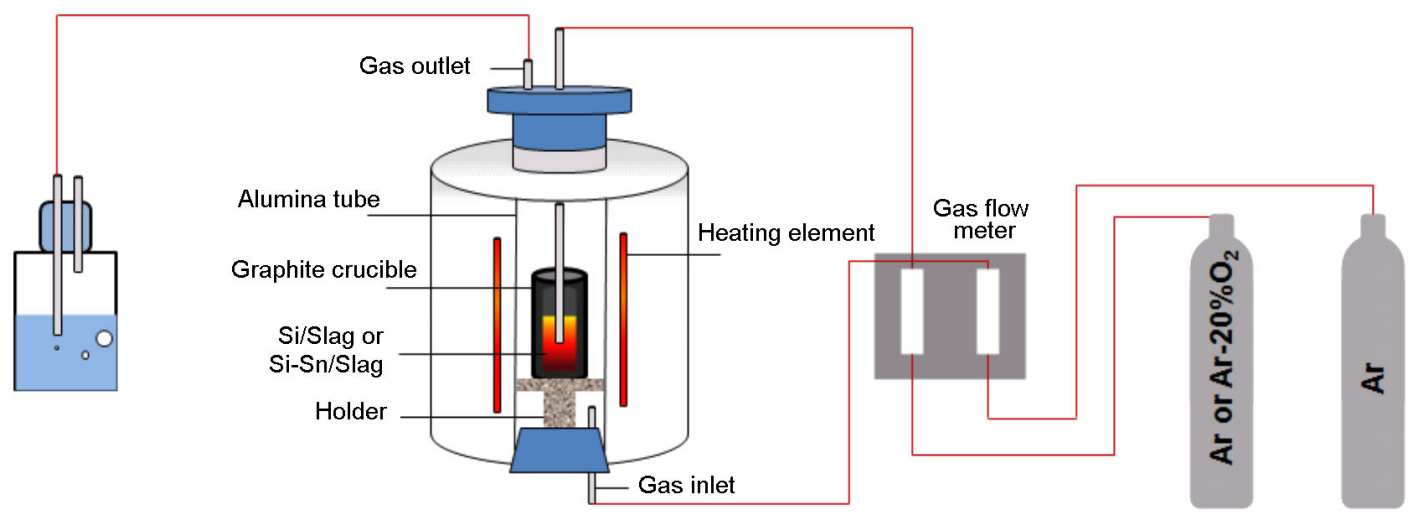

Fig. 1. MG-Si, $75 \%$ Si-Sn alloy slag refining with gas blowing.

with $(50,150$, and 250$) \mathrm{ml} / \mathrm{min}$ gas flow rate. The results shown in Fig. 2 .

In both Si and Si-Sn alloy, B concentrations decreased with increasing the flow rate of $\mathrm{Ar}$ gas which is an inert gas. This can be explained as increasing the gas flow rate led to increasing the stirring of the melt which results increasing in the kinetic energy of the slag refining reaction. In addition, increasing gas flow rate led to an alloy/slag increased in the reaction interface area between alloy/slag and consequence increasing in the $B$ removal.

3.2 Gas type using Ar-20\% $\mathrm{O}_{2}$ gas effect with slag refining on $B$ removal

In order to enhance the $B$ removal from Si by the combined process of slag refining and gas blowing, blowing $\mathrm{O}_{2}$ gas was performed to rise up the oxidation reaction and consequence having a better B removal. Blowing $\mathrm{O}_{2}$ gas in $\mathrm{Si}$ refining process considers an effective method to remove impurities directly from the MG-Si melt and promote B elimination by volatilization as B gaseous species such as BO [19]. In this experiment, the $\mathrm{O}_{2}$ gas ratio was set with $20 \%$ in the $\mathrm{Ar}-\mathrm{O}_{2}$ mixed gas to avoid unnecessary Si oxidation as SiO vapor [20]. The results of $\mathrm{Ar}-20 \% \mathrm{O}_{2}$ gas blowing into Si-Sn slag refining with different holding time and fixed gas flow rate $150 \mathrm{ml} / \mathrm{min}$ are shown in Fig.3.

The results shows that increasing holding time will decrease the final B concentration in the refined $\mathrm{Si}$ and the $\mathrm{B}$ removal efficiency was highly improved by combining the slagging and the gas blowing refining process. The B content in both of Si and $75 \%$ wt Si-Sn alloy decreased sharply in the first $60 \mathrm{~min}$ but there were no further de-

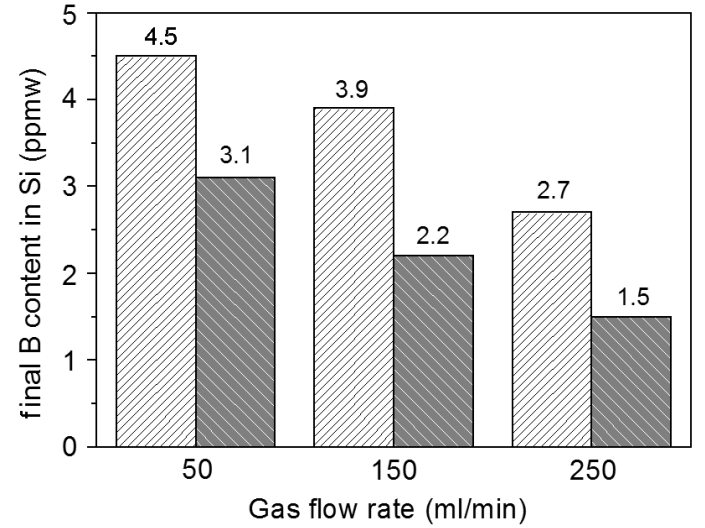

Fig. 2. Ar gas flowing rate effect in B removal with slag refining

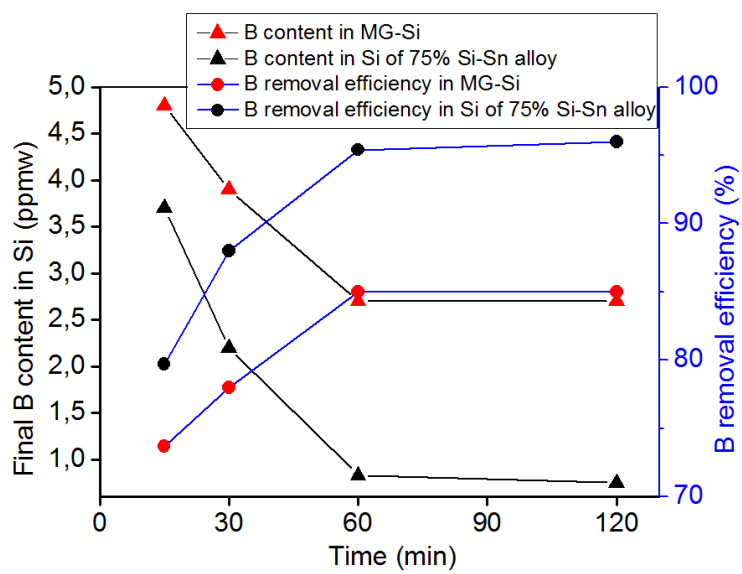

Fig. 3. Holding time effect in slag refining combined with $\mathrm{Ar}-20 \% \mathrm{O}_{2}$ gas blowing on $\mathrm{B}$ removal from MG-Si and $75 \%$ Si-Sn alloy.

creasing with further holding time. That indicates that reaction equilibrium was reaching in $60 \mathrm{~min}$. the maximum $\mathrm{B}$ removal efficiency in MG-Si was $85 \%$ while the maximum efficiency in $75 \%$ wt Si-Sn alloy 
Table 2. Final Compositions for the $\mathrm{CaO}-\mathrm{SiO}_{2}-\mathrm{CaCl}_{2}$ Slag System after reaction with 75 wt \% Si-Sn Alloys at $1500{ }^{\circ} \mathrm{C}$ for different holding time

\begin{tabular}{||c|c|c|c|c|c|c||}
\hline & $\mathrm{CaO} \%$ & $\mathrm{SiO}_{2} \%$ & $\mathrm{CaCl}_{2} \%$ & $\mathrm{Al}_{2} \mathrm{O}_{3} \%$ & $\mathrm{MgO} \%$ & Basicity \\
\hline Initial & 45 & 45 & 10 & 0 & 0 & 1 \\
After 30 min & 41.28 & 37.7 & 4.95 & 13.7 & 2.37 & 1.09 \\
After 60 min & 39 & 35 & 2.1 & 19.3 & 4.6 & 1.1 \\
After 120 min & 38.8 & 33.2 & 1.9 & 21.7 & 4.4 & 1.17 \\
\hline
\end{tabular}

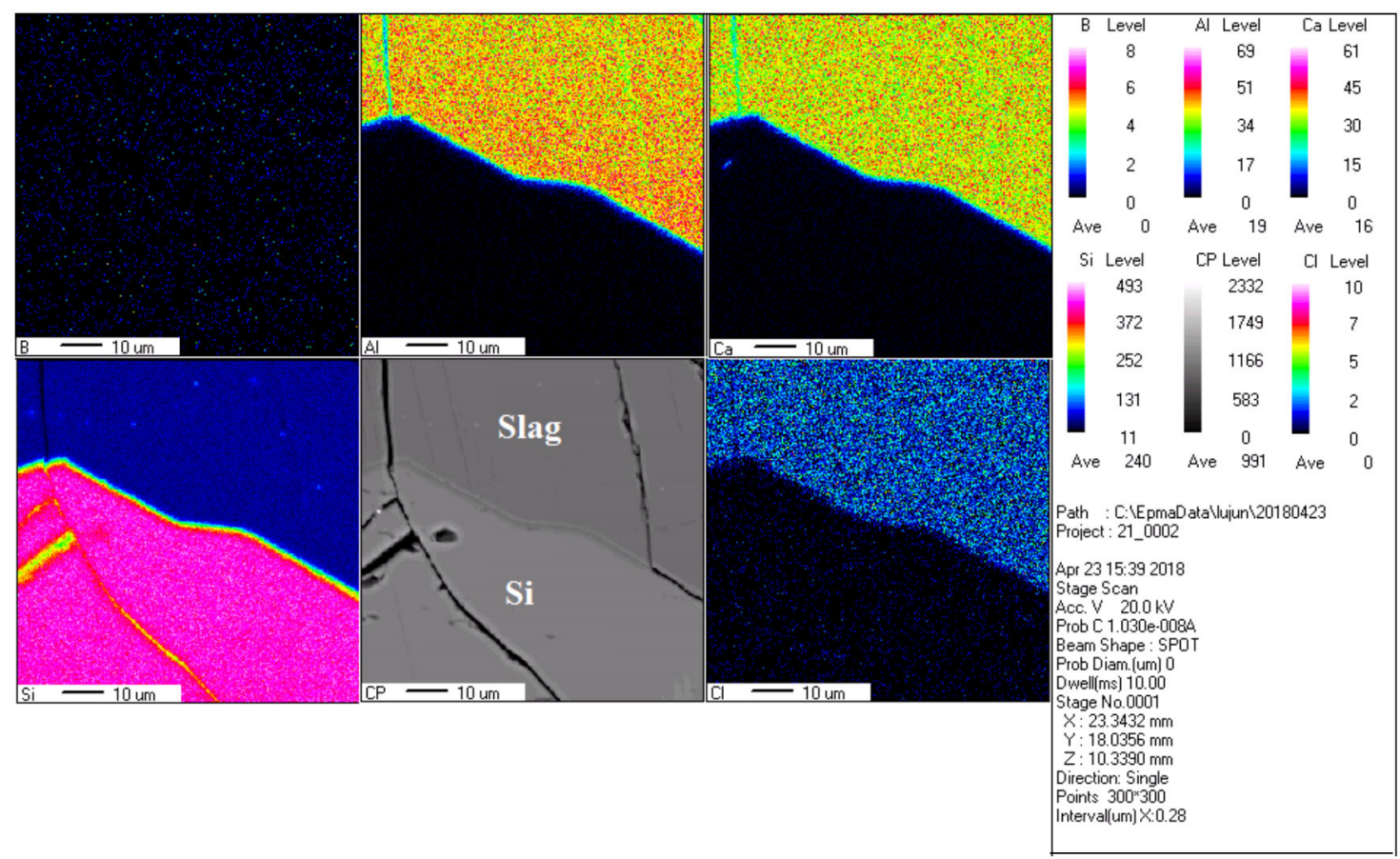

Fig. 4. Distribution of the elements in MG-Si after 45 wt $\%$ CaO-45 wt \% $\mathrm{SiO}_{2}-10$ wt $\% \mathrm{CaCl}_{2} \mathrm{slag}$ treatment combined with $\mathrm{Ar}-20 \% \mathrm{O}_{2}$ gas blowing.

was $96 \%$. The result with using $\mathrm{Ar}-20 \% \mathrm{O}_{2}$ mixed gas in the gas blowing was better comparing to the result of using only Ar gas in the process. The reason back to blowing $\mathrm{O}_{2}$ into the $\mathrm{CaO}-\mathrm{SiO}_{2}-\mathrm{CaCl}_{2}$ slag promote removal the $B$ as calcium borate $\left(3 \mathrm{CaO} \cdot \mathrm{B}_{2} \mathrm{O}_{3}\right)$ into slag and volatilization of $\mathrm{B}$ gaseous species as $\mathrm{BO}$ and $\mathrm{BOCl}$.

The initial slag composition used was $45 \% \mathrm{CaO}-45 \% \mathrm{SiO}_{2}-10 \% \mathrm{CaCl}_{2}$. During the slag reaction and with increasing holding time, there was changing in the slag mass ratio representing mainly by decreasing in all the compounds and specially the $\mathrm{CaCl}_{2}$ due to the evaporation in the high temperatures and participation in B removal as $\mathrm{BOCl}$ gas. Additionally, there are increasing in $\mathrm{Al}_{2} \mathrm{O}_{3}$ and $\mathrm{MgO}$ ratio because of the reaction between the melt and alumina tube which was used to transfer the gas for gas blowing technique. Table 2 shows the changes in slag mass ratio in slag refining combined with gas blowing in different holding time.

To further explore the element distribution subsequent to combined method of slag refining and gas blowing technique, the EPMA-mapping method was applied. Through analysis, it could be observe from Fig.4 elements distribution in MG-Si after the combined process. Both of Si phase and slag phase can be seen. The $\mathrm{Ca}, \mathrm{Cl}$, and $\mathrm{Si}$ can found clearly in the slag phase because they are the main materials of the slag. The Al was found in high intensity in the slag phase due to the reaction between slag phase and submerged alumina lance in slag which used to transfer the gas during das blowing process. The B impurities were found in all over the sample but with rela- 


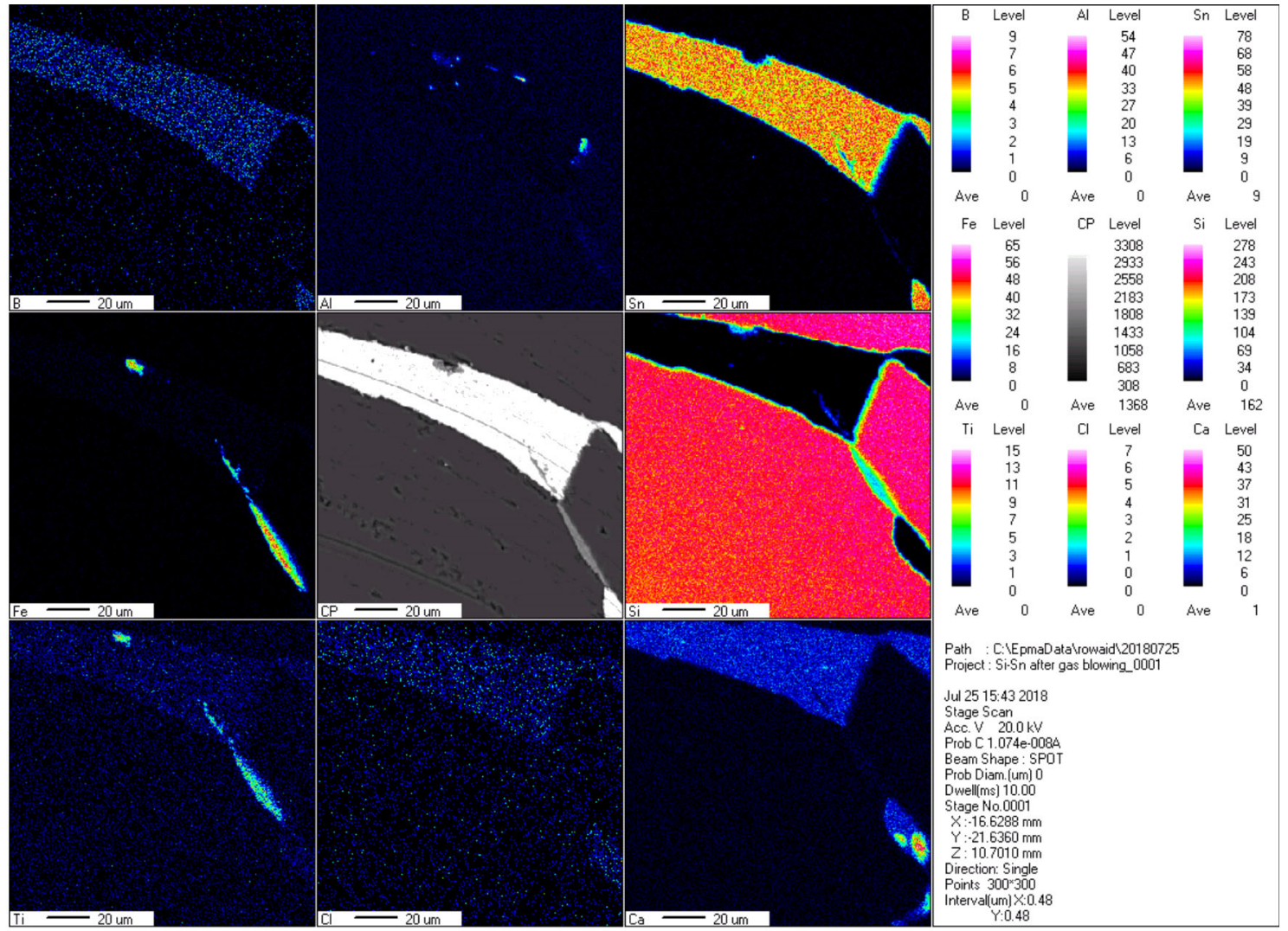

Fig. 5. Distribution of the elements in $75 \mathrm{wt} \% \mathrm{Si}-\mathrm{Sn}$ alloy after $45 \mathrm{wt} \% \mathrm{CaO}-45 \mathrm{wt} \% \mathrm{SiO} 2-10 \mathrm{wt} \%$ $\mathrm{CaCl}_{2}$ slag treatment combined with $\mathrm{Ar}-20 \% \mathrm{O}_{2}$ gas blowing

tive high intensity in the slag phase due to the mass transfer of $\mathrm{B}$ from $\mathrm{Si}$ to the slag through the oxidation reaction. The $\mathrm{Ca}, \mathrm{Al}$, and $\mathrm{Cl}$ were found with low intensity in $\mathrm{Si}$ phase.

Figure 5 shows the elements mapping in Si-Sn alloy. It can be seen that impurities $B$, $\mathrm{Ti}, \mathrm{Fe}$, and $\mathrm{Ca}$ were relatively concentrated in Sn phase of the alloy than in Si. The results indicate that solidification of liquid alloy may set the B distribution because $\mathrm{Sn}$ in Si-Sn alloy shows higher affinity for B than Si solid phase. This led to low segregation coefficient of B between Si solid phase and $S n$ liquid phase resulting in effective $B$ getting by $\mathrm{Sn}$ in Si-Sn alloy. The $\mathrm{Al}$ impurity was concentrated in the Si phase after $45 \% \quad \mathrm{CaO}-45 \% \quad \mathrm{SiO}_{2}-10 \% \quad \mathrm{CaCl}_{2}$ slag treatment because of the relatively large segregation coefficient of $\mathrm{Al}$ in molten Si. During solidification process of Si-Sn alloy, Al impurity will reject to the $S n$ liquid phase. Due to the high cooling rate in the experiment, Al impurities had insufficient time to transfer to Sn liquid phase and therefore it will be found in low concentration randomly across the alloy and in high concentration in the front area between Si/Sn phases. The Fe impurity phase was found in the sample attaching to $\mathrm{Sn}$ phase because $\mathrm{Fe}$ has a low segregation coefficient in the Si-Sn alloy and favors segregation in the Sn phase during solidification [21] which can be easily removed together with $S n$ by acid leaching.

The slag refining reaction takes place through mass transfer in Si, Si-Sn, by chemical reaction in the interface between metal and slag, mass transfer in slag phase, and evaporation from surface to the gas phase. The overall mass transfer coefficient can be calculated based on the results obtained from the concentrations of $B$ in the slag and $\mathrm{Si}, \mathrm{Si}-\mathrm{Sn}$ alloy. It can be concluded that the reaction at the interface of slag and Si, Si-Sn alloy reach equilibrium since the concentration of $B$ remained unchanged. The molar flux of impurity can be expressed as below:

$$
n_{\mathrm{B}}=\frac{d}{d t} \frac{M[\% \mathrm{~B}]}{100 M_{S^{A}} A_{S}}
$$




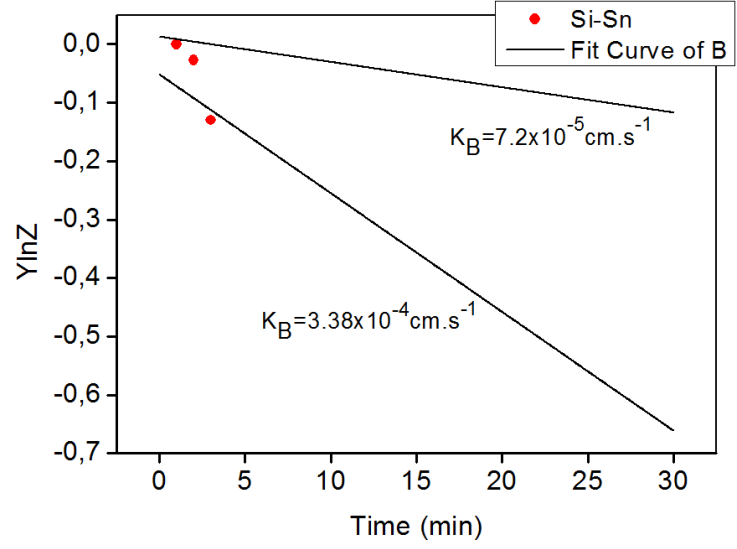

Fig. 6. Relationship between $Y \ln Z$ and holding time.

Arranging equation (1) to the B flux and can be expressed as equation (2)

$$
n_{\mathrm{B}}=\frac{\rho k_{t}}{100 M_{B}}([\% B])-\frac{(\% B)_{\gamma_{B}}}{K f_{B}}
$$

where $\rho$ is the metal density, $\gamma_{B}$ and $f_{B}$ are the equilibrium coefficients of boron in slag and silicon, $K$ is the equilibrium constant of the oxidation reaction, and $k_{t}$ is the total mass transfer coefficient. The equilibrium constant $K$ can express as:

$$
K=\frac{(\% B) \gamma_{B}}{[\% B] f_{B}}
$$

The $\mathrm{B}$ partition ratio defined flowing:

$$
L_{B}=\frac{(\% B)}{[\% B]}
$$

where $(\% \mathrm{~B})$ represent the $\mathrm{B}$ concentration in slag phase and [\% B] the $\mathrm{B}$ concentration in Si phase. The relationship between the mass transfer coefficient and time written as equation (5):

$$
\frac{M}{\rho A_{S}\left(1+\frac{M}{L_{B} M_{S}}\right)} \ln \frac{[\% B]-[\% B]_{e}}{[\% B]_{i n}-[\% B]_{e}}=-k_{t} t
$$

where $M$ and $M_{S}$ represents the mass of Si, Si-Sn alloy and slag. Equation (5) can be represented in the form as below:

$$
Y \ln Z=-k_{t} t
$$

According to equation (6), a plot of $(Y \ln Z)$ vs. time is a straight line with a slope $K_{B}$ when the mass transfer is the rate controlling step. Fig. 6 shows the linear re-
Table 3. Final B content with holding time to MG-Si and 75 wt\% Si-Sn alloy till equilibrium

\begin{tabular}{|c|c|c|c|c||}
\hline & \multicolumn{2}{|c|}{ MG-Si } & \multicolumn{2}{c||}{$75 \mathrm{wt} \%$ Si-Sn } \\
\hline $\begin{array}{c}\text { Time } \\
\text { (min) }\end{array}$ & B (ppmw) & $L_{B}$ & B (ppmw) & $L_{B}$ \\
\hline 15 & 4.6 & 1.8 & 9.25 & 0.34 \\
30 & 3.9 & 2.3 & 5.5 & 1 \\
60 & 2.7 & 3.6 & 1.24 & 6.5 \\
\hline
\end{tabular}

gression of the mass transfer coefficient of $B$ when equation (6) is applied. The mass transfer coefficients of $B$ were $3.38 \cdot 10^{-}$ ${ }^{4} \mathrm{~cm} . \mathrm{s}^{-1}$ and $7.2 \cdot 10^{-5} \mathrm{~cm} . \mathrm{s}^{-1}$ in Si and Si-Sn alloy respectively with following information in Table 3.

\section{Conclusions}

Combined method of slag refining with gas blowing technique was performed to enhance $B$ removal from $\mathrm{MG}-\mathrm{Si}$ and $75 \mathrm{wt} \%$ Si-Sn alloy using $\mathrm{Ar}$ and $\mathrm{Ar}-20 \% \mathrm{O}_{2}$ gaseous. The gas blowing enhances $\mathrm{B}$ removal through promoting slagging by stirring the melt to increase reaction rate.

Increasing gas flow rate led to increase the $B$ removal. Where $B$ content decrease from 4.5 ppmw and 3.1 ppmw in both Si and Si-Sn alloy, respectively with $50 \mathrm{ml} / \mathrm{min}$ flow rate to $2.7 \mathrm{ppmw}$ and $1.5 \mathrm{ppmw}$ in Si and Si-Sn, respectively with increasing the flow rate to $250 \mathrm{ml} / \mathrm{min}$ under fixed conditions of time and temperature with the use of Ar gas.

Blowing Ar-20\% O $\mathrm{O}_{2}$ mixed gas shows better results from $\mathrm{Ar}$ gas blowing due to the oxidation effect of this gas which enhances the B removal.

Increasing holding time in $\mathrm{Ar}-20 \% \mathrm{O}_{2}$ gas blowing with slag refining led to decrease the $B$ content and increase the removal efficiency up to 60 min holding time. Further increasing in holding time shows no changing in the results.

The changes in the slag compositions with increasing holding time representing by decrease in $\mathrm{CaCl}_{2}$ content due to the evaporation in high temperatures and reaction with $\mathrm{B}$ to produce $\mathrm{BOCl}$ gas. Increasing in $\mathrm{Al}_{2} \mathrm{O}_{3}$ content in the slag compositions due the reaction with alumina lance. Changing in the slag basicity from 1 to 1.17 .

It was found that the kinetics controlled by mass transfer of $B$ in slag phase with mass transfer coefficients of $3.38 \cdot 10^{-4} \mathrm{~cm} \cdot \mathrm{s}^{-1}$ and $7.2 \cdot 10^{-5} \mathrm{~cm} \cdot \mathrm{s}^{-1}$ in Si and Si-Sn alloy respectively. 
Acknowledgments

The authors are grateful for support from the National Science Foundation China (Grant No. 51334002, No. 51604023), Beijing Key Laboratory of Green Recycling and Extraction of Metals (GREM), the Laboratory of Green Process Metallurgy and Modeling (GPM2) and the High Quality steel Consortium (HQSC) at the School of Metallurgical and Ecological Engineering at University of Science and Technology Beijing (USTB), the Chinese government scholarship information System C.S.C, China.

\section{References}

1. Adolf Goetzberger, Christopher Hebling, Solar Energy Mater. Solar Sells, 62, 1, (2000)

2. Hans Joachim Moller, Claudia Funke, Markus Rinio, Sandra Scholz, Thin Solid Films, 487, 179, (2005).

3. Sergio Pizzini, Solar Energy Mater. Solar Sells, 94, 1528, (2010).

4. Huixian Lai, Liuqing Huang, Huaping Xiong, et.al., Industr. Engin. Chem. Res., 56, 311, (2016).

5. Arafune Koji, Ohishi Eichiro, Sai Hitoshi, et.al., J. Crystal Growth, 308, 5, (2007).

6. Yun Lei, Wenhui Ma, Guoqiang Lv, et al., Separ. Purification Techn., 173, 364, (2017).

7. K.Suzuki, N.Sano, Thermodynamics for removal of boron from metallurgical silicon by flux treatment, in Tenth EC Photovoltaic Solar Energy Conference,1991, pp. 273-275

8. Jiangtao Wang, Xiaodong Li, Yongmin He, et al., Separ. Purif. Techn., 102, 82, (2013).

9. J. C. S. Pires, A. F. B. Braga, P. R. Mei, Solar Energy Mater. Solar Sells, 79, 347, (2003)

10. N Yuge, M Abe, K Hanazawa, H Baba, et.al., Progress Photovoltaics: Res. Appl, 9 203, (2001)

11. Jijun Wu, Yeqiang Zhou, Wenhui Ma, Min $\mathrm{Xu}$, Bin Yang, Metallurg. Mater. Trans. B. 48, 22, 2017

12. AA Istratov, T Buonassisi, RJ McDonald, AR Smith, et.al. J. Appl. Phys., 94, 6552, (2003)

13. Ji-jun Wu, Yan-long Li, Kui-xian WEI, YANG Bin, Yong-nian DAI, Trans. Nonferrous Metals Soc. China, 24, 1231, (2014).

14. Y.Wang, X.Ma, K.Morita, Metallurg. Mater. Trans. B. 45 334, (2014)

15. J.Wu, W.Ma, B.Jia, B.Yang, D.Liu, Y.Dai, J.Non-Crystalline Solids, 358,3079, (2012)

16. M.D. Johnston, M. Barati, Solar Energy Materi. Solar Cells. 94, 2085, (2010)

17. L. A. V.Teixeira, K.Morita, ISIJ Intern., 49 783, (2009).

18. Ernst Christian Koch, Dominik Clement, Propellants, Explosives, Pyrotechnics. 32, 205, (2007).

19. Kichiya Suzuki, Tomonori Kumagai, Nobuo Sano, ISIJ Intern. 32, 630, (1992)

20. David Lynch, Jom. 61,41, (2009)

21. R. H. Hopkins, A. Rohatgi, J. Crystal Growth, 75, 67, (1986). 